1981 Particle Accelerator Conference - March 11-13, 1981

Outgassing Rate of the Copper-plated Beam Iube for ISABELLE*

H. C. Hseuh, and $E, E$, Gaudet

Brookhaven National Laboracory

Upton, New Yark 11973

Summary

The ultrahigh vacuum sygtem of the intersecting storage accelerator. ISABELLE, w11l consist of two interlaced rings of stainless steel bear tubes with a circumference 2ir miles each. To obtain a good heat conduction during bakeout and to reduce the resistive wall Enctab1l1ty during beam operation, a lma thick copper coating will be electroplated to the outer surface of this 1.5m thick beam eube. To minimize the beam loss due to beam-gas collision, che gressure inside the beam cube is required to be $1 \times 10^{-11}$ Torr (N, equivaleat) or less. To achieve this ulerahigh vacuüm, the outgassing rate of the $304, \mathrm{~L}$ stainless steel tubes has been reduced to $011 \times 10^{-13^{2}}$ Torr. $q / \mathrm{cm}^{2}$. sec by vacuum firing at $250^{\circ} \mathrm{C}$ for one hour. However, during acid-bath electroplating of copper, significaut amount of hydzogen wil be rel-croduced and trapped in stainless steel which will arbstancfallv increase t!:e outgassing rate (to $42 \times 10^{-12}$ Torr! $/ \mathrm{cm}^{2}$. Jec). The outgassing characteriscics of these copper-plated beam tubes art studled and discussed within the scope of diffusion and enerky of activacion. Yethods to reduce the outgasging rate to an acceptable level $\left(n+1 \times 10^{-13}\right.$ Torr $\left.\cdot 2 / \mathrm{cm}^{2}-\mathrm{sec}\right)$ ara also given.

\section{¿. Latroduction}

The Intersecting Storage Accelerator, ISABELLE, currently under construction at Brookhaven Sational Laboratory, consists of two rings having a circumference of $3.8 \mathrm{~km}$ each. To provide a very clean environment for the circulating proton beam, the ultrainigh vacuum (Liv) svsten of ISABELLE 1s designed to operate at an average pressure of $1 \times 10^{-11}$ Torr ( $N_{2}$ equivalene) This IHV system consists of $0,14009.8 \mathrm{~cm}$ diameter, $5.5 \mathrm{mo}$ long stainless steel beam subes pumped by a combination of titanium subltmation pumps (, $1000 \mathrm{~V} / \mathrm{sec}$ each) and sputter ins pumps (^20 i/sec each). The choice of $304 \mathrm{LN}$ stainless steel as beam tube materlal as well as the reed of cooper sleeve on the outer surface or beam tubes ias been described previously.

the ullimate pressure achievabie ingide such long rubes will depend on the pumping speeds of the 1on pura and :- subltimator, the conductance of the tubes and the ottgassing rate of the bean cube material. The rirst zso paramesers are governed by the desiza of the other s.rstems (superconducting magnets, cryogenics, etc.). The cutgassing rate of the bean subes siould, therefore be iswered as much as possible. The outgassing rate of $\because$ acuum- Ffred (ac $950^{\circ} \mathrm{C}$ with pressure $<1 \times 10^{-5}$ Tort $693^{5}$ 1 hour) $304, i N$ stafinless steel beam tube 1 is $\sim 1 \times 10^{-13}$ Torr. ? $\cdot \mathrm{cm}^{-2} \cdot \mathrm{sec}^{-1}$ (Ref 3 ) which is acceptable.

The enormous force gererated on the copper sleeve durting the quench of superconducting magness limits the aethod of copoer coating to electroplating. Signif1cart arount of indrogen will be refntroduced fnto statrIass steel during electropiating. This trapped hydrojen w1: later diffuse through statniess steel fnte Wriv sysem and substantfally fncreage the outgassing sate.

This paper descrtbes the reasurements of the outgassing rate of several stataless steel tuies with and it thour electroplated copper on the ourer surface. The ef jecss of hest treatment a:e 11 so digcussed within the scope of diffusion, and energy of actuation.

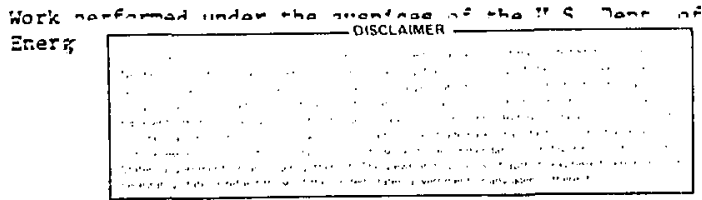

\section{Measurements}

The setur used in our study of the outgassing rate of the sample eubes is shown schematically in Fig. 1. Samole tube with one end sealed was attached through the bakeable valve to the monftoring chamber which was separated from the punping station (with a pumping speed $210002 / \mathrm{sec}$ for hydrogen) by a copper gasket havIng an 8nom diameter orffice. A Bayard-ilpert trpe 1onization guage (with $x-r a y$ limit lass than $1 \times 10$ Torr) was used to measure the oressure inglde the mon1toring chamber.

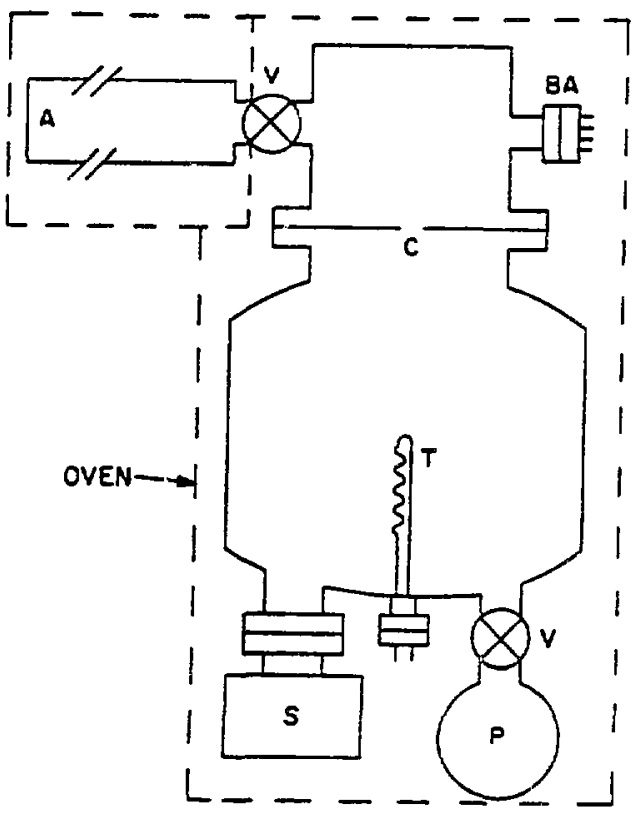

Figure 1: Expertmental secup for outgassing measurezents. A. '. sample tube; $V$. - bakeable valve: BA. Bayard Alpert type ionfzation gauge: $C$. - orf $f_{1 c e}$ T. - Titanium sutilmator: S. - sputter ton aum: P. - Turbomolecular pump.

The calibrated conductance method 3,4 which measures the gas flow across the orifice was used in our study to obtala the outgassing rate 0 of the sample tube. $Q$ can be exiressed as

$O\left(\right.$ Torr. $\left.\mathrm{cm}^{-2} \mathrm{sec}^{-1}\right)=C \times \Delta P / \mathrm{A}$

where $A$ is the cotal inner suriace area of the sample tube, $\Delta P$ is the change of the pressure inside the zen1toring shamber between open aud close of the bakealie raive, and $C$ is the conductance of the ortitice. A raiue of $204 / \mathrm{sec}$ for $C$ was used ía our calcularion since $>95 \%$ of the outzassed spectes was found to be hydrogen, ${ }^{\circ}$. The surface area $A$ of each sample tuoe was ., $7600 \mathrm{~cm}^{2}(3.3 \mathrm{~cm} 0.0 ., 1.5$ II val1 and 2.75 जo long). The baciground pressure of the nontrortag chamber wh bakeable vaive close sas $<3 \times 10^{-1+}$ Torr vileh en-

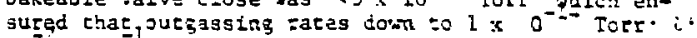
$\mathrm{cm}^{-2}$. $\mathrm{sec}^{-1}$ uere jerecrable. 


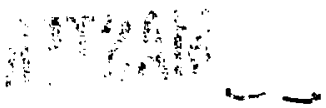

Iable I Dutgassing rates $Q$ of the sample tubes* after gequential bakeouts

Sequential Bakeout Conditions

Iemp. ( $\left.{ }^{\circ} \mathrm{C}\right)$ Duration (hr.)

$$
\text { Outgassing Race (Torr } 2 \cdot \mathrm{cm}^{-2} \cdot \mathrm{sec}^{-1} \text { ) }
$$

$\mathrm{Cl} \quad \mathrm{C2} \quad \mathrm{C3}$

$\mathrm{C} 4$

D

\begin{tabular}{|c|c|c|c|c|c|c|c|c|}
\hline 300 & 24 & $2 \times 10^{-13}$ & $2 \times 10^{-12}$ & $3 \times 10^{-12}$ & $2 \times 10^{-12}$ & & $2 \times 10^{12}$ & $2 \times 10^{-12}$ \\
\hline 300 & 70 & & $2 \times 10^{-13}$ & $1 \times 10^{-12}$ & $6 \times 10^{-13}$ & $7 \times 10^{-13}$ & $1 \times 10^{-12}$ & $1 \times 10^{-12}$ \\
\hline 500 & 24 & & & $1 \times 10^{-13}$ & $1 \times 10^{-13}$ & $2 \times 10^{-13}$ & $3 \times 10^{-14}$ & $3 \times 10^{-13}$ \\
\hline
\end{tabular}

$\star 304$ LN staliless steel tubes 3.5" 0.D., $0.060^{\prime \prime}$ wall, 9 ' long with the following treatments: Sample A: vacum fired at $950^{\circ} \mathrm{C}$ for one hour at a pressure less than $1 \times 10^{-4}$ Torr. Sample B: unfired

Samples $\mathrm{Cl}-\mathrm{C}_{4}$ : vacuum fired at $950^{\circ} \mathrm{C}$ for one hour; electroplated with $I$ m thick copper on the outer surface Sample D: unfired; electroplated as Samples Cl-C4.

After chemically cleaning, some sample tubes vere vacuum fired (at $e 1 \times 10^{-4}$ torr and at $950^{\circ} \mathrm{C}$ for $1 \mathrm{hr}$ ), sealed tien electroplated with $\sim$ lm thick copper, whlle others were elther electroplated or vacuum fired.

These sample tubes were then mounted on the rest setuo for outgassing measuremencs.

Afte. the sample tubes had been baked out at elther $300^{\circ} \mathrm{C}$ or $500^{\circ} \mathrm{C}$ for destred perlods of time, the outgasslag rates were deterwined usine the callhrated condisetance method described above. The bakeout conditions is weli as the obtained outgassing rate for these sample tubes are ligted in Table I. To understand the origin and the rechanism of the ourgassing, measurements were also made at elevated temperacures. The results wer. oloted out in Finure 2 as a function of ceaperature.

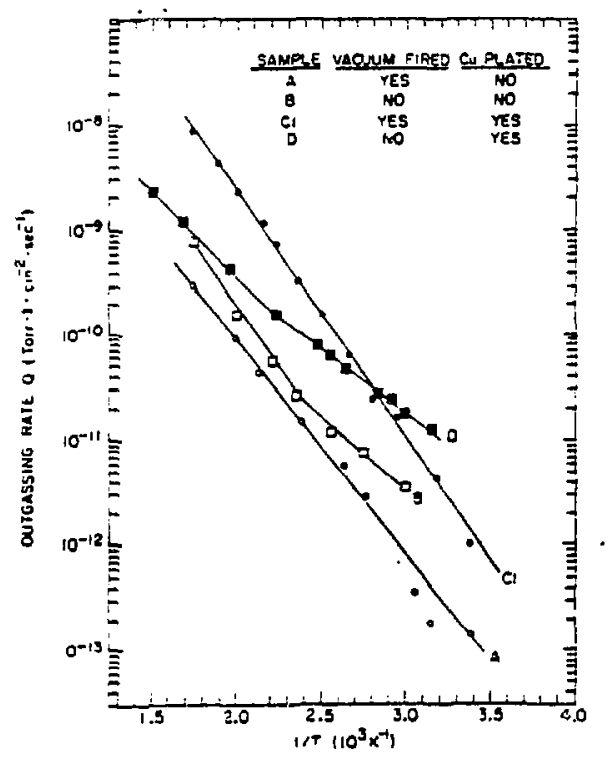

F1gure 2: Jutzasglag race of the statiless steel tubes as 3 tunction of the emperature.

III. Kesults and Discussion.

if ter the tnit lal $24 \mathrm{ir}$. bakeour at $300^{\circ} \mathrm{C}$. the ourgass 17 race of che rachum itred cube (sample 2 ) ras

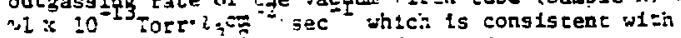

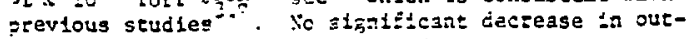

gassine race was ot jerved after further bakeauts. The vacuun-f1red electroslaced tubes (samp $19 \mathrm{~s}(1-\mathrm{C} 4)$
showed outgassing rates around $2 \times 10^{-12}$ Torr. $2 . \mathrm{cm}$ $\sec ^{-1}$ after the 1nitial bakeout. These were significant1y higher than those of the unplaced cubes (1.e. sample

A). The outgassing rates of the plated tubes were reduced about one half after consecuctue bakeouts at $3 n n^{\circ} \mathrm{r}$. $A$ redugtion of the outgassing rate to $* 1 \times 10^{-13}$ Tort. 2. $\mathrm{cm}^{-2}$. $\mathrm{sec}^{-1}$ (the acceptable outgassing rate for ISABELLE beam cube) was achleved only after a $24 \mathrm{hr}$. bakeout at $500^{\circ} \mathrm{C}$.

The outgasing races of two unfired tubes were also studied. The electroplated tube (sample D) had ourgassing rates similar to those of the vacuum fired then electroplated tubes. After the Initlal bakeout, the outgassing race of the unfired tube (sample $B$ ) was consistent with that reported by thalama? qoweves it dropped off rapidiy to $2 \times 10^{-13}$ Torr.2. $\mathrm{cm}^{-2} . \mathrm{sec}$ after the second $300^{\circ} \mathrm{C} 70$ hour bakeout. More seasureJerts on other unfired and unblated tubes are in progress to verlfy these results.

The rate controlling step and mechanisw of the outgassing from stainless steel tubes (elther vacuur fired or not, and elther electroplated or not) can be understood qualitatively Erom the heat of diffusion (JE) of hydrogen which is the only diffusable gas inside the bulk of the stalinless steel. By ploting the outgassIng race as a function of senperacure, as shown in figure 2, the heats of diffusion $\triangle E$ can be calculated from the slopes of the curyes according to

$$
Q=Q_{0} e^{-}
$$

wheze $\mathrm{Q}$ is the gas constant ( $1.99 \mathrm{cal}: \mathrm{K}^{-1}$;. The measured IE values for both the electroplated tube (sample Cl) and the bare stainless sceel tube (sarole $A$ ) are 1 t $1 \mathrm{Kcal} /$ mole. This similarily in heat of diffusion suggests that the rate determining steo in both cubes is the diffusion of iydrogen through stainless steel and the presence of the electroplaced copper has little tafluence.

The measured $\Delta \Sigma$ values for the tro unflred tubes (samples $B$ and D) are several Kcal/oole lower than those of the vacum fired tubes: at lower temperacuza $\left(T<160^{\circ} \mathrm{C}\right)$ the zeasurad $\triangle E$ values for these tro rubes algo decrease somewhat. These vartations in heat of diffusion with temperature and between vaccum fired tubes and unfired tubes can be expla!ned qualitativei: on the basis of lateice difiusion and grain boundary diffusion (phase boundary diffusion).

Barrer classified the diftuston of gases (espectally hydrogen) in metal into two najor categortes: the lateice diffusion and the grain boundary diffuston. The accivation enerzy required for grain boundary diffuston is less than that of tattice ditfusion, therefore, at lower temperature the grain boundar: diffusion process accuis uch nore rapidly than lat:1ce diffuston. The vacuun firfing process and iigh temperatuze bakenut anneal the stainiess steel, and enhance she arowtin ? the crystalitres in the scainless sceel yt: 
lowers the amount of grain boundary diffusion. The slopes of curves in Figure 2 suggest that the lattice diffusion process dominates the vacuum fired tubeg whIle the unfired tubes rontala a alxture of lattice diffuston and grain boundary diffusion with grain boundary diffusion dominating at lower temperatures.

\section{Conelusion}

The vacuum fired stainfegss steel tuhes haye an outgassing rate of $v_{1} \times 10^{-13}$ Torr $\ell \cdot \mathrm{cm}^{-2} \cdot \mathrm{sec}^{-1}$ which can meet the pressure requirement of the ISABELIE UHV system, therefore, can be used as the ISABELLE beam tubes. The additional hydrogen entrapped into stainless steel during the electroplating of copper rafses the outzassing rate $q f$ the ${ }^{3}$ stainles steel tube to $42 \times 10^{-12}$ Torr $\cdot h \cdot \mathrm{cm}^{-2} \cdot \mathrm{sec}^{-1}$. By baking-aue at higher temperature (1.e. $500^{\circ} \mathrm{C}$ for 24 hours), the outgass 158 rate could ${ }_{2}$ be lowered to acceptable level ( $1 \times 10^{\circ}$ Torr $2 \cdot \cos ^{-2} \cdot \sec ^{-1}$ ).

The ortgin and mechanism of outgassing can be classified as elther lattice diffusion or grain boundary diffuston or 3 mixture of both. The lattice diffuglon process is the dominant process in vacuum ftred tubes, while the diffuston process of the unfired tubes contalns the mixture of the lattice and the grain boundary.

With 3 an expected outgassing rate of $\sim_{1} \times 10^{-13}$

Torr $\cdot \mathrm{l} \cdot \mathrm{cos}^{-2} \cdot \mathrm{sec}^{-1}$ for the ISABELLE beam tubes (after electroplating and high temperature bakeout), the achievable pressure insice the bead tubes can be estinated according to

$$
P(x)=\mathrm{PO}_{0}+\mathrm{Q}\left[\frac{i}{\mathrm{~S}}+\frac{3}{\vec{C}}\left(\mathrm{~L}-\frac{\mathrm{x}}{2}\right)\right]
$$

There $P_{0}=$ the pressure at pumping station ( $5 \times 10^{-12}$ Torr)

$Q$ - outgassing rate $\left(1 \times 10^{-13} \mathrm{Torr} \cdot 1 \cdot \mathrm{cm}^{-2} \cdot \mathrm{sec}^{-1}\right)$

L one-half the distance betreen pumping station $(275 \mathrm{~cm})$

S - pumping speed at pumplag station (10002/sec $-10^{\circ} \mathrm{cm} / \mathrm{sec}$ )

$x$ - distance fron pumping station ( $x=L$ at cencer of beam tube)

C - conductance of beam cube per unis Iergth (3.1 $\left.\times 10^{\prime} \mathrm{cm} / \mathrm{sec}\right)$

The pressure haltway between purning sfations (higher pressure bump) w1ll be $20+4 \times 10^{-12}$ Tort. and the averagedpressure inside the baam tubes w111 be $\mathrm{Po}+3 \times 10^{-12}$ Tors.

7. Ackrowledgements

The authors :ould 1 the to shank $H$. Aalawa and I. S. Chou fo. their valuable concrfbutions.

V1. Reference

1. J. Aggus, D. Eduards, Jr.. H. J. Halama and J. Herrera, 1979 Partfcle Acceieracor Conference, San Eranisco, CA. Yar. 12-14, 1979.

2. R. ?. Shute, private comonication

3. H. J. halema, J. Vac. Sc1. Technol. 16, 717 (1979)

4. H. J, Halana and J. C. Herrera, J. vac. 5c1. Technol. , 13,403 (1979)

5. H. J. Halama, privace comunicat

5. R. Calder and G. Lerin, Brit. J. Appl. Phys., 18, $1459(1967)$.

T. R. Y. Barrer, "Diffusion In ane Through Solidg", Cambridge University Press, London (1951), Chapter 4.

3. G. Lewin "Eundamentals of Vacisum Sclence and Technoloty", MeGraw-H11I Inc,. New York (1965), pp8536 . 